\title{
The effect of freeze-dried Carica papaya leaf juice treatment on NS1 and viremia levels in dengue fever mice model
}

Mohd Ridzuan Mohd Abd Razak* (D), Norazlan Mohmad Misnan', Nur Hana Md Jelas', Nor Azrina Norahmad, Amirrudin Muhammad', Tiffiny Chau Dee Ho' ${ }^{1}$ Bazilah Jusoh¹, Umi Rubiah Sastu', Murizal Zainol', Mohd Isa Wasiman', Hussin Muhammad ${ }^{1}$, Ravindran Thayan² and Ami Fazlin Syed Mohamed ${ }^{1}$

\begin{abstract}
Background: Carica papaya leaf juice (CPLJ) was well known for its thrombocytosis activity in rodents and dengue patients. However, the effect of CPLJ treatment on other parameters that could contribute to dengue pathogenesis such as nonstructural protein 1 (NS1) production and viremia level have never been highlighted in any clinical and in vivo studies. The aim of this study is to investigate the effect of freeze-dried CPLJ treatment on NS1 and viremia levels of dengue fever mouse model.

Methods: The dengue infection in mouse model was established by inoculation of non-mouse adapted New Guinea C strain dengue virus (DEN-2) in AG129 mice. The freeze-dried CPLJ compounds were identified by UltraHigh Performance Liquid Chromatography High Resolution Accurate Mass Spectrometry analysis. The infected AG129 mice were orally treated with $500 \mathrm{mg} / \mathrm{kg} /$ day and $1000 \mathrm{mg} / \mathrm{kg} /$ day of freeze-dried CPLJ, starting on day 1 post infection for 3 consecutive days. The blood samples were collected from submandibular vein for plasma NS1 assay and quantitation of viral RNA level by quantitative reverse transcription PCR.

Results: The AG129 mice infected with dengue virus showed marked increase in the production of plasma NS1, which was detectable on day 1 post infection, peaked on day 3 post-infection and started to decline from day 5 post infection. The infection also caused splenomegaly. Twenty-four compounds were identified in the freeze-dried CPLJ. Oral treatment with $500 \mathrm{mg} / \mathrm{kg} /$ day and $1000 \mathrm{mg} / \mathrm{kg} /$ day of freeze-dried CPLJ did not affect the plasma NS1 and dengue viral RNA levels. However, the morbidity level of infected AG129 mice were slightly decreased when treated with freeze-dried CPLJ.

Conclusion: Oral treatment of $500 \mathrm{mg} / \mathrm{kg} /$ day and $1000 \mathrm{mg} / \mathrm{kg} /$ day of freeze-dried CPLJ at the onset of viremia did not affect the plasma NS1 and viral RNA levels in AG129 mice infected with non-mouse adapted New Guinea C strain dengue virus.
\end{abstract}

Keywords: Dengue, AG129 mice, Carica papaya leaf, nonstructural protein 1, viremia

\footnotetext{
* Correspondence: ridzuan@imr.gov.my

${ }^{1}$ Herbal Medicine Research Center, Institute for Medical Research, Kuala

Lumpur, Malaysia

Full list of author information is available at the end of the article
}

(C) The Author(s). 2018 Open Access This article is distributed under the terms of the Creative Commons Attribution 4.0 International License (http://creativecommons.org/licenses/by/4.0/), which permits unrestricted use, distribution, and reproduction in any medium, provided you give appropriate credit to the original author(s) and the source, provide a link to the Creative Commons license, and indicate if changes were made. The Creative Commons Public Domain Dedication waiver (http://creativecommons.org/publicdomain/zero/1.0/) applies to the data made available in this article, unless otherwise stated. 


\section{Background}

Globally, up to 390 million dengue infections are estimated to occur yearly and 3.9 billion people are at risk of infection with dengue virus in over 128 endemic countries [1]. The person infected with dengue virus may develop a flu-like illness called febrile dengue and may progress into a lethal complication called severe hemorrhagic dengue [1]. The dengue virus is transmitted by female Aedes mosquito from infected human to other healthy human [1]. The virus comprises 4 serotypes, DEN-1, DEN-2, DEN-3 and DEN-4 which belong to the genus Flavivirus, family Flaviviridae [1]. To date, there is no specific anti-viral drugs for dengue treatment as most of the potential candidates failed to reduce viremia and antigenemia levels in clinical studies [2]. Although the dengue vaccine such as Dengvaxia is available, the efficacy of this vaccine is limited to seropositive individuals or individuals who have been infected with dengue [3].

In a descriptive cross-sectional study conducted in the hospital setting in Malaysia, CPLJ was among the popular complementary alternative medicine used by the patients with dengue fever after isotonic drinks and crab soup [4]. Indeed, the thrombocytosis effect of CPLJ have been previously documented in several clinical trials and case studies conducted on dengue patients [5-12]. The thrombocytosis activity of the Carica papaya leaf juice (CPLJ) and extracts have been scientifically proven in vivo either in healthy rodents or thrombocytopenic induced rats [13-19]. In addition, the treatment of $C$. papaya leaf aqueous extract has been shown to decrease the bleeding and clotting time in thrombocytopenic induced rats [13]. The actual mechanism of thrombocytosis activity induced by CPLJ is still unknown. The potential compounds that exhibited the thrombocytosis activity could be derived from the alkaloids [19], phenolics and flavonoids which were majorly found in CPLJ $[13,16]$.

Besides the thrombocytosis effect, other factors related to dengue severity or pathogenesis such as viremia and NS1 antigenemia developments have not been addressed in any in vivo and clinical studies involving CPLJ. Dengue virus NS1 contributed to dengue pathogenesis by inducing plasma leakage [20] through the activation of apoptosis [21], Toll-like receptor 4 [22] and expression of sialidases and heparanase from the endothelial cells, which could disrupt the endothelial glycocalyx layer [23]. It was also reported to be involved in thrombocytopenia by exhibiting autoantibody production, which caused the platelet phagocytosis by the macrophages [24] during dengue virus infection. Therefore, the NS1 level could potentially be used as a marker for dengue severity and any efforts in perturbing the NS1 production either by affecting the virus replication or host mediated NS1 secretion pathways may potentially reduce the burden of dengue patients. In addition, the potential of quercetin, a compound presence in CPLJ, to inhibit the dengue viral replication has been demonstrated by in silico [25] and in vitro [26] studies.

The AG129 mouse, lacking the interferon $\alpha / \beta$ and $\gamma$ receptors, was first reported as a reliable dengue mouse model by Johnson and Roehrig in 1999 [27] after establishing the infection with a mouse-adapted DEN-2 virus strain, New Guinea C (NGC) [27]. In human infection, dengue virus replicates successfully by inhibiting interferon signaling. However, the inhibition of interferon signaling by dengue virus was not successful in mouse [28]. So, with the absence of interferon $\alpha / \beta$ and $\gamma$ receptors, the immune response related to interferon signaling was impaired. Hence, the AG129 mouse become susceptible to viral infection such as dengue, vaccinia, lymphocytic choriomeningitis [29] and Zika viruses [30]. The AG129 mouse was commonly used as a dengue fever and dengue hemorrhagic in vivo models in many preclinical drug discovery studies [31-34]. Depending on dengue virus strain, the infected AG129 mice could mimic several major pathologies of human dengue infection such as high level of viremia, overproduction of proinflammatory cytokines, vascular leakage and thrombocytopenia [35-38]. Thereby, this study has established the dengue fever mouse model by inoculation of non-mouse adapted DEN-2 dengue virus strain, NGC, which was used as a test system to study the effect of freeze-dried CPLJ treatment on NS1 antigenemia and viremia developments.

\section{Methods}

\section{Animal ethics statement and husbandry}

All animal experiment procedures were carried out under the guidelines and upon approval of the Animal Care and Use Committee, Ministry of Health Malaysia (ACUC-MOH), (ACUC/KKM/02(9/2016). The AG129 mice $(129 / \mathrm{Sv}$ mice deficient in both alpha/beta and gamma interferon receptors) (5-6 weeks old) were obtained from Marshall BioResources, United Kingdom. All experiments were conducted in the GLP-certified Non-Clinical Research Facility, Laboratory Animal Research Unit, Medical Research Resource Center, Institute for Medical Research, Kuala Lumpur, Malaysia. The animals were received artificial light, 12 hours light and 12 hours dark. The experimental room's temperature was maintained within the range $19^{\circ} \mathrm{C}$ to $26^{\circ} \mathrm{C}$. All experiment procedures on mice were conducted by trained personnel and assisted by the veterinarian. The mice were housed in individual ventilated cages supplied with reverse osmosis drinking water and mouse pellet ad libitum. Prior to the experiment, the mice were quarantined for 2 weeks and acclimatized for 1 week. 


\section{Experimental design}

The experiments were carried out independently in two phases, the establishment of dengue fever mouse model and the efficacy evaluation of freeze-dried CPLJ. For the establishment of dengue fever model in AG129 mice, 7 to 8 weeks old male mice were randomly assigned into four groups comprised of one mock infected group (inoculated with plain media) $(n=5)$ and three infected groups. The mice in each of infected group were inoculated with $2 \times 10^{3} \mathrm{PFU}(n=5), 2 \times 10^{4} \mathrm{PFU}(n=5)$ and $2 \mathrm{X} 10^{5} \mathrm{PFU}(n=5)$ of dengue virus. The whole bloods $(\sim 250 \mu \mathrm{l})$ were collected through submandibular vein on day $1,3,5,7$ and 9 post infections for NS1 assay and viral RNA quantitation as mentioned in the following sections. All mice were euthanized on day 11 post infection. For this phase of experiment, the higher inoculation titer $\left(2 \mathrm{X} 10^{6} \mathrm{PFU}\right)$ was not tested due to the limited titer of virus stock. There are several factors or conditions that influenced the production of virus stock with higher titer such as culture conditions, timing of virus harvesting, choice of host cell types and virus strains [39-41]. The virus harvesting in this study was based on the observable cytopathic effect (CPE) of infected host cells, which seem to result in limited titer of virus stock. However, virus harvesting at the exponential phase of viral production, after kinetic evaluation, has led this study to obtain a higher virus titer for the second phase of the experiment.

For the efficacy evaluation of freeze-dried CPLJ, the mice were inoculated with $2 \mathrm{X} 10^{5} \mathrm{PFU}$ intraperitoneally. In addition, an independent experiment was done on mice infected with higher inoculation titer, $2 \mathrm{X}_{10} 0^{6} \mathrm{PFU}$, which produced higher lethality rate than the mice infected with $2 \times 10^{5}$ PFU dengue virus (Additional file 1). The AG129 mice were randomly assigned into 4 groups comprised of mock infected group (mock infected + distilled water) $(n=5)$, treatment control group (mock infected $+1000 \mathrm{mg} / \mathrm{kg} \mathrm{BW}$ of CPLJ) ( $n=5)$, infected group (infected + distilled water) $(n=5)$ and treatment group (infected $+500 \mathrm{mg} / \mathrm{kg} \mathrm{BW}$ of CPLJ) $(n=5)$. The morbidity level of each mice was observed and monitored as mentioned in previous section for 30 days post infection. In addition, another independent experiment was done to evaluate higher treatment dose of freeze-dried CPLJ, $1000 \mathrm{mg} / \mathrm{kg} \mathrm{BW}$. For this experiment, three groups of mice; mock infected group $(n=5)$, infected group $(n=5)$ and treatment group $(n=5)$ were used. The preparation of freeze-dried CPLJ for dosing is as mentioned in the following section.

\section{Cell and dengue virus propagation}

The mosquito C6/36 and monkey kidney Vero cells were purchased from American Type Culture Collection (ATCC, USA). C6/36 cells were grown at $28^{\circ} \mathrm{C}$ in
Leibovitz's L-15 medium supplemented with $2 \%$ FBS, $10 \%$ tryptose phosphate broth, $100 \mathrm{U} / \mathrm{ml}$ penicillin G and $100 \mu \mathrm{g} / \mathrm{ml}$ streptomycin. Vero cells were grown in DMEM medium supplemented with $10 \%$ fetal bovine serum, $35 \mathrm{mM}$ sodium bicarbonate, $100 \mathrm{U} / \mathrm{ml}$ penicillin $\mathrm{G}$ and $100 \mu \mathrm{g} / \mathrm{ml}$ streptomycin at $37^{\circ} \mathrm{C}$ in $5 \% \mathrm{CO}_{2}$ Galaxy $170 \mathrm{~S}$ incubator (New Brunswick, Germany).

The DEN-2 dengue virus stock, New Guinea $C$ strain (NGC) (ATCC VR-1584) was grown in C6/36 cells at $28^{\circ} \mathrm{C}$ in Leibovitz's L-15 medium. The titer of dengue virus was quantified by plaque assay. Briefly, $4.5 \times 10^{5}$ of Vero cells were grown in a 6-well plate containing 1.5 ml DMEM medium for 24 hours until confluent. Then, the media was discarded and replaced with $100 \mu \mathrm{l}$ of C6/36 cell supernatant containing virus suspension. The viruses were allowed to infect the Vero cells for one hour. One $\mathrm{ml}$ of an overlay medium containing $1 \%$ agarose in 1X DMEM medium was added to Vero cell monolayers and incubated for 7 days at $37^{\circ} \mathrm{C}$ in $5 \% \mathrm{CO}_{2}$ incubator. The Vero cell monolayers were stained with $1 \%$ crystal violet in $20 \%$ ethanol leaving clear unstained plaques resulted from virus infection. The infectivity titre was expressed as the number of plaque forming units per $\mathrm{ml}(\mathrm{PFU} / \mathrm{ml})$.

\section{Dengue virus inoculation and morbidity monitoring}

The AG129 mice were inoculated with DEN-2 dengue virus strain, NGC, via intraperitoneal route according to the titers mentioned in previous section. At 24 hours post infection, the body weight of the mice was recorded daily. The sign of illness was monitored twice a day and scored based on 1 to 5 scale: 1-healthy; 2-mild sign of lethargy and ruffled fur; 3-intermediate level of lethargy, ruffled fur and hunched posture; 4-very lethargy, ruffled fur, hunched posture and limited mobility; 5-moribund with limited to no mobility and inability to reach food or water [42]. Mice exhibiting weight loss more than $20 \%$ of initial body weight or moribund or paralyzed during the study were euthanized immediately by open-drop exposure to isoflurane. Euthanized mice during the study were counted as being dead on the following day for analysis [35]. At the end of the study, the survived mice were euthanized by open-drop exposure to isoflurane by the veterinarian in the fume hood. None of the mice died before meeting criteria for euthanasia.

\section{Freeze-dried C. papaya leaf juice preparation}

Fifty grams of $C$. papaya fresh green leaves from 'Sekaki' cultivar, were collected from the herbal garden of the Institute for Medical Research, Malaysia. The C. papaya was identified by Ms. Tan Ai Lee, a botanist from the Forest Research Institute of Malaysia (FRIM). The voucher specimen was deposited in the FRIM, Kepong, Malaysia (Voucher No: 007/10). The C. papaya trees 
were planted organically without the use of pesticides and herbicides. Only healthy leaves (without ring spot) were selected for the juice preparation. The leaves were cleaned thoroughly with veggie wash (to remove wax and soil) followed by washing with reverse osmosis water and extracted using Panasonic juicer Mj68 (Shah Alam, Malaysia) without any addition of water in a biosafety cabinet class II. The remaining husk was pressed using a clean laboratory cloth. The juice was then placed in a sterile container and frozen at $-50^{\circ} \mathrm{C}$ before subjected to freeze drying process in a freeze-dryer Alpha 1-2 LD Plus (Martin Christ, Germany) to obtain the powdered form of the juice, freeze-dried CPLJ.

\section{Ultra-High Performance Liquid Chromatography-High Resolution Accurate Mass Spectrometry (UHPLC-HRAMS) analysis}

The following reference standards were purchased from Extrasynthese (Genay, France): quercetin-3-O-rutinoside (rutin), kaempferol-3-O-rutinoside (nicotiflorin), 1,2-dihydroxybenzene (catechol), ferulic acid, morin and isorhamnetin. Kaempferol, 5,7-dimethoxycoumarin (citropten), p-coumaric acid, caffeic acid, fisetin, chlorogenic acid, 3,4-dihydroxybenzoic acid (protocatechuic acid), quercetin, quinic acid, and malic acid were purchased from Sigma-Aldrich (Madrid, Spain). All solvents used for the preparation of sample and mass spectrometry analysis was liquid chromatography mass spectrometry (LCMS) graded solvent purchased from Merck (Darmstadt, Germany).

The analysis was performed by using the Thermo Scientific Dionex Ultimate 3000 Series RS pump coupled with a Thermo Scientific Dionex Ultimate 3000 Series TCC-3000RS column compartments and a Thermo Fisher Scientific Ultimate 3000 Series WPS-3000RS autosampler controlled by Chromeleon 7.2 Software (Thermo Fisher Scientific, Waltham, MA and Dionex Softron GMbH Part of Thermo Fisher Scientific, Germany). Separations were performed by using a ACQUITY UPLC ${ }^{\circledast}$ CORTECS C18 analytical column $(2.1 \mathrm{~mm} \times 50 \mathrm{~mm}$; particle size, $1.6 \mathrm{~m})$ (Waters, Milford, MA, USA) equipped with a Van Guard BEH C18 pre-column $(2.1 \mathrm{~mm} \times 5 \mathrm{~mm}$; particle size, $1.7 \mathrm{~m})$ (Waters, Milford, MA, USA) maintained at $40^{\circ} \mathrm{C}$. The mobile phase consisted of solutions A $(0.1 \% \mathrm{v} / \mathrm{v}$ formic acid in water $)$ and $B(0.1 \% \mathrm{v} / \mathrm{v}$ formic acid in acetonitrile solution). A gradient program was used for elution including $5 \%$ solution B initially, with $5-30 \%$ solution B from 0 to $3 \mathrm{~min}, 30-90 \%$ solution $B$ from 3 to $8 \mathrm{~min}$, and $90 \%$ solution $\mathrm{B}$ from 8 to $11.5 \mathrm{~min}$. A $4 \mathrm{~min}$ equilibration was adopted before the next injection. The mobile phase was delivered at a flow rate of $0.3 \mathrm{~mL}$ per min.
HRAMS data were acquired using a Thermo Scientific Q-Exactive Orbitrap mass spectrometer controlled by the Xcalibur 2.3 software (Thermo Fisher Scientific, Waltham, MA) and operated at 70,000 resolution in full scan and 35,000 in MS/MS scan mode. The key heat electrospray ionization (HESI) source parameters were optimized as follows: spray voltage, $3.5 \mathrm{kV}$; capillary temperature, $320 \mathrm{C}$; sheath gas flow, $30 \mathrm{~L}$ min1; auxiliary gas, $10 \mathrm{~L} \min 1$; sweep gas, $5 \mathrm{~L}$ min1; heater temp, 350 C; S-lens RF level, $55 \%$. The scope of full scan was from 50 to $500 \mathrm{M} / \mathrm{Z}$. Data-dependent MS/MS analysis was performed with normalized collision energy of $30 \mathrm{~V}$ and a $\mathrm{M} / \mathrm{Z}$ isolation window of 4 atomic mass units (AMU). Accurate $\mathrm{m} / \mathrm{z}$ of the detected peaks were then extracted in Xcalibur $(\mathrm{m} / \mathrm{z}$ window of $5 \mathrm{ppm})$ to confirm their presence. Identification of the potential detected compounds were based on their accurate $\mathrm{m} / \mathrm{z}$ and observed isotopic clusters, obtained in the MS mode, as well as on their MS/MS fragmentation patterns and the accurate $\mathrm{m} / \mathrm{z}$ of the resulting product ions.

\section{Dosing preparation}

The selection of doses for this study were based on the general toxicology studies of freeze-dried CPLJ in Sprague Dawley rats, which were conducted previously by our lab [43-45]. The findings indicated that freeze-dried CPLJ was not toxic up to $2000 \mathrm{mg} / \mathrm{kg}$ as no mortality nor adverse effect was observed in rats [43-45]. The therapeutic dose was calculated based on the clinical trial study of CPLJ on dengue patients conducted previously [12]. Briefly, about $2400 \mathrm{mg}$ of $C$. papaya juice powder was produced after freeze drying of $30 \mathrm{ml}$ juice, which was previously consumed by dengue patients once a day for three consecutive days [12]. So, the dose consumed by a normal weight $(60 \mathrm{~kg})$ dengue patient was calculated as $40 \mathrm{mg} / \mathrm{kg} \mathrm{BW/day.} \mathrm{After} \mathrm{conversion} \mathrm{to}$ animal equivalent dose [46], the calculated dose was 500 $\mathrm{mg} / \mathrm{kg} \mathrm{BW/day.} \mathrm{So,} \mathrm{the} \mathrm{dosing} \mathrm{regimen} \mathrm{for} \mathrm{this} \mathrm{study} \mathrm{was}$ $500 \mathrm{mg} / \mathrm{kg}$ BW once a day for 3 consecutive days. The oral treatment was done by using oral gavage on day 1 post infection to allow complete virus dissemination in the mouse circulation. The dosing volume was calculated so that it meets the $10 \mathrm{ml} / \mathrm{kg}$ bodyweight requirement. Treatment of infected AG129 mice with higher dose of freeze-dried CPLJ (1000 mg/kg BW) was also done independently using similar study design as mentioned in the previous section. In addition, the uninfected AG129 mice given $1000 \mathrm{mg} / \mathrm{kg} \mathrm{BW/day} \mathrm{freeze-dried} \mathrm{CPLJ} \mathrm{alone}$ remained healthy throughout this experiment (Fig. 4).

\section{Whole blood and plasma collection}

The blood withdrawal was performed by submandibular vein puncture technique (facial vein), which is recommended for periodic blood collection on mice and 
provide a fast recovery time of the puncture wound [47]. Whole blood was collected $(250 \mu \mathrm{l})$ in EDTA microtainer tube. The whole blood was processed for plasma collection. The blood was centrifuged for 15 minutes at $2000 \mathrm{x} \mathrm{g}$ at $4^{\circ} \mathrm{C}$. The plasma was immediately transferred into a separate clean $1.5 \mathrm{ml}$ microcentrifuge tube for the purpose of NS1 assay and real-time PCR virus quantitation. The plasma was stored at $-40^{\circ} \mathrm{C}$ for future use.

\section{Quantitation of NS1 level in plasma}

Five microliters of plasma were subjected to NS1 assay using the Platelia Dengue NS1 Ag assay kit (Bio-Rad, USA) according to the manufacturer instruction with some modifications. Briefly, $5 \mu \mathrm{l}$ of plasma was diluted with $45 \mu \mathrm{l}$ of phosphate buffered saline (PBS, $\mathrm{pH}$ 7.2). Then, $10 \mu \mathrm{l}$ of diluted plasma was mixed with $40 \mu \mathrm{l}$ of R7 solution and transferred into 96 well plate. Another $50 \mu \mathrm{l}$ of R7 solution was added prior to the addition of $100 \mu \mathrm{l}$ diluted peroxidase-conjugated NS1 monoclonal antibody solution. The mixture of sample and antibody solution were incubated for 90 minutes at $37^{\circ} \mathrm{C}$. Then, the microplate was washed as described by the manufacturer. The reaction was started by the addition of chromogen solution and allowed to develop in the dark for 30 minutes at room temperature. The enzymatic reaction was stopped by the addition of stopping solution (1N sulfuric acid solution) in each well. The optical density was measured at $450 \mathrm{~nm}$ using a microplate reader (FLUOstar Omega, BMG Labtech, Germany).

\section{Detection and quantification of viral RNA}

The dengue virus titer in the plasma was determined by viral RNA quantification using quantitative reverse transcription PCR (qRT-PCR), which has been shown to be more sensitive and kinetically correlated with the direct viral count by plaque assay technique [48]. The viral RNA was extracted from the plasma according to the manufacturer instruction using QIAamp Viral RNA Mini kit (Qiagen, USA). The purified viral RNA was subjected to qRT-PCR (Applied Biosystems 7500 fast, USA) as described by Chutinimitkul et. al. [49] using QuantiTect SYBR ${ }^{\circ}$ Green RT-PCR detection kit (Qiagen, USA). The dengue viral RNA with known copy number was used as a standard for copy number determination.

\section{Data analysis}

The ANOVA with multiple comparison test was used for comparison between groups. The differences between groups were considered significant when the $P$ value was less than 0.05 . The Kaplan Meier survival curves was constructed for each control and treated groups and the difference between groups was analyzed using log-rank test.

\section{Results}

The establishment of dengue fever model in AG129 mice

The peak of NS1 level depends on the initial viral load. The level of plasma NS1 in the AG129 mice infected with $2 \times 10^{4} \mathrm{PFU}$ and $2 \times 10^{5} \mathrm{PFU}$ peaked at day 3 post infection and start to decline from day 5 to day 7 post infection until it was not detected on day 9 post infection (Fig. 1a). In contrast, AG129 mice inoculated with lower viral load, $2 \times 10^{3} \mathrm{PFU}$, showed a delay in NS1 production where it only peaked on day 7 post infection and declined on day 9 post infection (Fig. 1a). As expected, the NS1 level remains undetected in mock infected AG129 mice group which were only inoculated with plain media (Fig. 1a). In addition to the sign of infection, the spleen of AG129 mice infected with $2 \times 10^{5}$ PFU viral load were significantly $(p<0.05)$ enlarged as compared to mock infected AG129 mice group (Fig. 1b) suggesting a strong inflammatory response to dengue infection in dengue fever mouse model. No obvious spleen enlargement was observed in AG129 mice with lower viral load.

\section{Qualitative analysis of freeze-dried CPL compounds by UHPLC-HRAMS}

Qualitative analysis was carried out on ultra-highperformance liquid chromatography coupled to ESI Q-Exactive orbitrap high-resolution accurate mass spectrometry in positive and negative modes in order to identify compounds present in the CPLJ samples. The potential calculated mass and fragmentation of the compounds associated with the measured mass of compounds were evaluated with Xcalibur software. The MS chromatograms (negative and positive ion modes) were shown in Fig. 2. Twenty-four compounds were detected in the freeze-dried CPLJ with some tentatively identified and some were identified by comparing with reference standards. Sixteen compounds such as quinic acid, malic acid, protocatechuic acid, chlorogenic acid, p-coumaric, caffeic acid, ferulic acid, rutin, nicotiflorin, myricetin, fisetin, morin, quercetin, kaempferol, citropten and isorhamnetin were identified based on mass spectra pattern and retention times with their reference standards. In total, 12 flavonoids, 5 hydroxycinnamic acids derivatives, 3 alkaloid compounds, 3 organic acids and 1 phenolic acid were tentatively identified and identified by reference standard in freeze-dried CPLJ as shown in Table 1.

\section{Effect of freeze-dried CPLJ on NS1 and viral RNA levels during dengue virus infection in AG129 mice}

In order to test the efficacy of freeze-dried CPLJ, the treatment was conducted independently on AG129 mice infected with $2 \times 10^{5}$ PFU and $2 \times 10^{6}$ PFU of NGC dengue virus. The AG129 mice inoculated with higher 

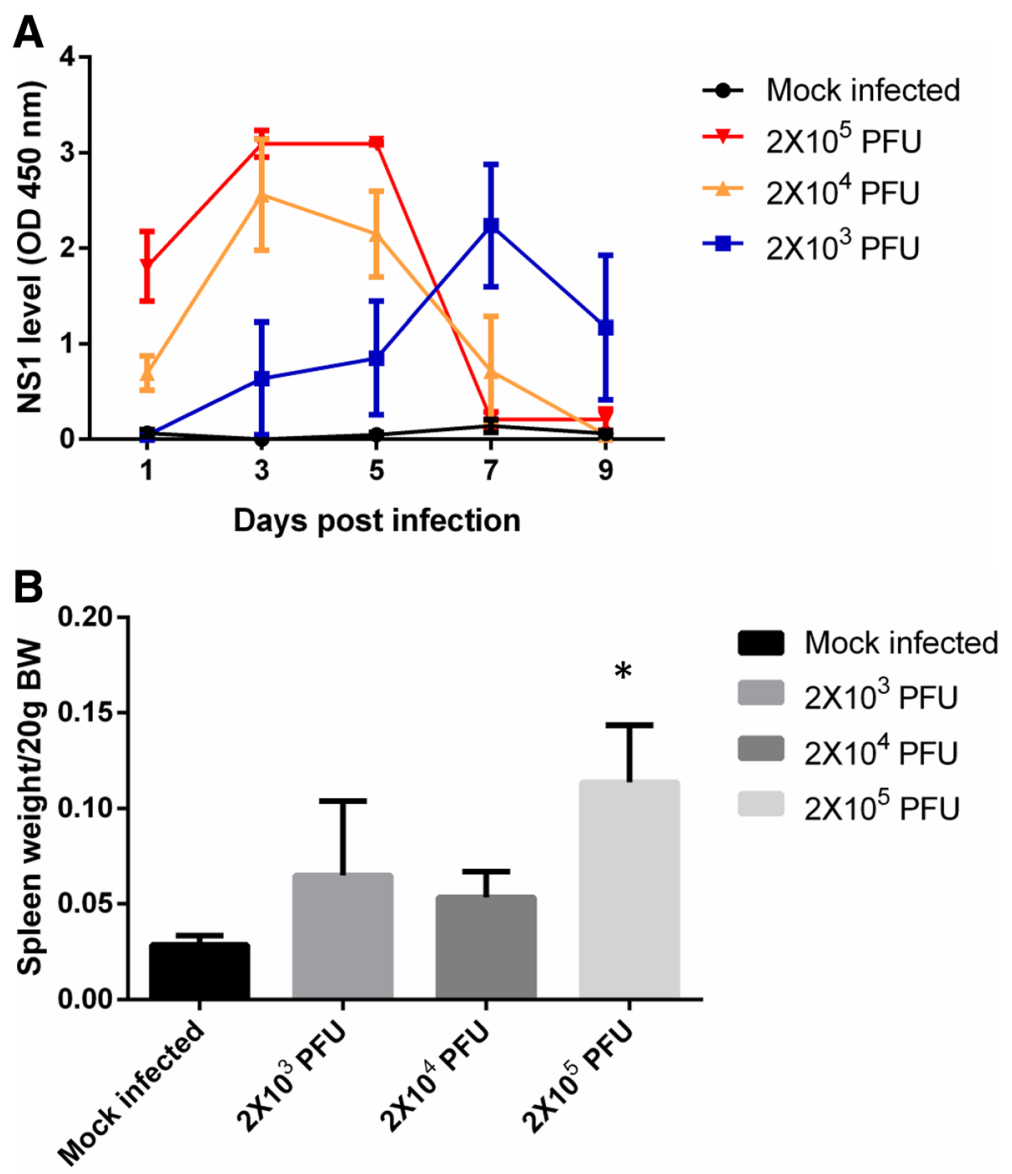

Experimental groups

Fig. 1 The AG129 mice infected with non-adapted serotype 2 NGC strain dengue virus developed NS1 antigenemia and splenomegaly. AG129 mice intraperitoneally infected with $2 \times 10^{3} \mathrm{PFU}$ or $2 \times 10^{4} \mathrm{PFU}$ or $2 \times 10^{5} \mathrm{PFU}$ of dengue virus strain NGC on Day 0 post infection. The mock infected mice group ( $n=5)$ were inoculated with $200 \mu$ l of media only. a The plasma NS1 level of mock infected (black circle) $(n=5)$ and infected $(n=5)$ (blue square: $2 \times 10^{3} \mathrm{PFU}$; yellow triangle: $2 \times 10^{4} \mathrm{PFU}$; red triangle: $2 \times 10^{5} \mathrm{PFU}$ ) AG129 mice groups were detected on day 1, 3, 5, 7 and 9 post infection by NS1 antigen immunoassay. Data represent mean values \pm standard error of the mean (SEM). $\mathbf{b}$ The spleens of mock infected $(n=5)$ and infected $(n=5)$ AG129 mice groups were harvested and weighed on Day 11 post infection. Data represent mean values \pm standard deviations (SD). The data comparison was done by using Tukey's multiple comparison ANOVA. Statistical significance $(p<0.05)$ is depicted with asterisks above the columns

viral titer, $2 \times 10^{6} \mathrm{PFU}$, was included in this study due to the higher lethality rate as compared to the mice infected with $2 \times 10^{5}$ PFU dengue virus (Additional file 1). The kinetic pattern of NS1 production in AG129 mice infected with $2 \times 10^{5} \mathrm{PFU}$ and $2 \times 10^{6} \mathrm{PFU}$ of dengue virus was unaffected by the oral treatment of $500 \mathrm{mg} / \mathrm{kg}$ BW freeze-dried CPLJ (Fig. 3a and b). The plasma viral RNA level of AG129 mice infected with $2 \times 10^{6}$ PFU was also not affected by the freeze-dried CPLJ treatment (Fig. 3c).

\section{Effect of freeze-dried CPLJ treatment on the morbidity level of dengue virus infected mice}

The AG129 mice infected with $2 \times 10^{6}$ PFU dengue virus showed the progression of the disease as the median body weight gradually decreased to more than $5 \%$ starting from day 7 to day 10 post infection (Fig. 4a). The infected AG129 mice treated with $500 \mathrm{mg} / \mathrm{kg}$ BW freeze-dried CPLJ (Infected+CPLJ 500) also showed a gradual decrease in the median bodyweight but limited to $5 \%$ on day 10 post infection (Fig. 4a). The body weight of mock infected AG129 mice group remained plateau till day 10 post infection (Fig. 4a). In addition, the mock infected AG129 mice receiving higher dose of freeze-dried CPLJ (Mock+CPLJ 1000), $1000 \mathrm{mg} / \mathrm{kg} \mathrm{BW,}$ also showed similar body weight pattern as the mock infected AG129 mice group till day 10 post infection (Fig. 4a) suggesting that there was no sign of toxicity or illness caused by the freeze-dried CPLJ alone on the healthy AG129 mice during the experiment.

The freeze-dried CPLJ treated AG129 mice infected with dengue virus showed a slight improvement in 


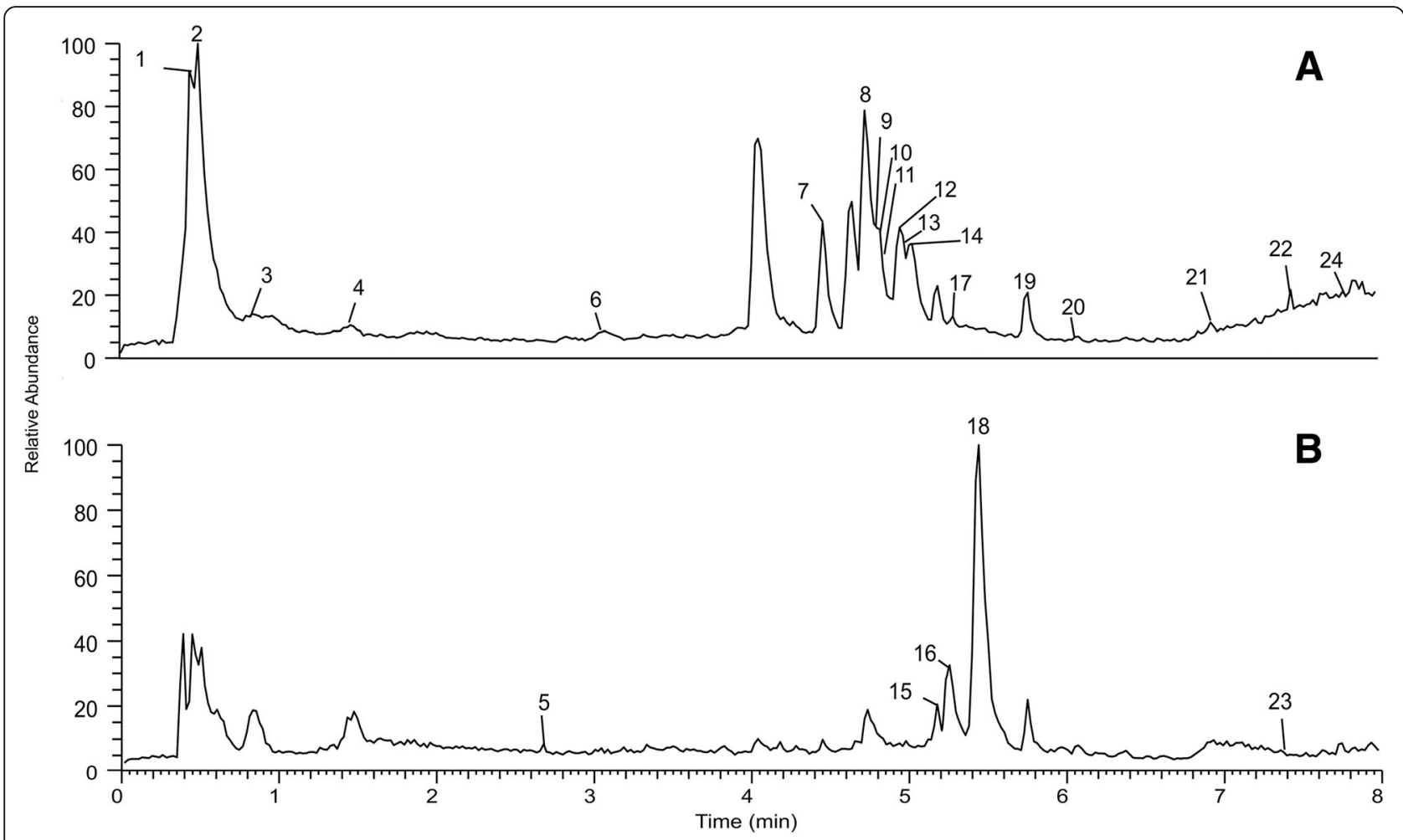

Fig. 2 Fingerprinting of freeze-dried CPLJ by UPLC-HRAMS analysis. Chromatograms of freeze-dried CPLJ was generated by UHPLC-ESI-OrbitrapMS/MS at (a) negative and (b) positive ionizations

survival rate as compared to infected AG129 mice without treatment. However, the difference was not statistically significant $(\mathrm{p}>0.05)$ (Fig. $4 \mathrm{~b})$. As neurological sign of illness is common in AG129 mice infected with dengue virus strain NGC, paralysis (complete paralysis of one or both hindlimbs) was observed in $40 \%$ of infected AG129 mice (Fig. 4c). Meanwhile, only 20\% of the freeze-dried CPLJ treated AG129 mice infected with dengue virus (Infected+CPLJ 500) developed paralysis (Fig. 4c).

The effect of $1000 \mathrm{mg} / \mathrm{kg}$ BW freeze-dried CPL treatment on plasma NS1 and viral RNA levels of dengue virus infected AG129 mice

In order to see whether there is a dose related effect of freeze-dried CPLJ on the dengue virus development in AG129 mice, a higher dose of freeze-dried CPLJ, 1000 $\mathrm{mg} / \mathrm{kg} \mathrm{BW}$, was used to treat the infected AG129 mice. It was clearly shown that after treatment with $1000 \mathrm{mg} /$ $\mathrm{kg} \mathrm{BW}$ of freeze-dried CPLJ, there was no significant difference in the NS1 level on day 3, 5 and 7 post infection as compared to mock infected AG129 mice (Fig. 5a). The plasma dengue viral RNA level was also not significantly affected by the treatment with higher dose of freeze-dried CPLJ (Infected+CPLJ 1000) (Fig. 5b).

\section{Discussion}

The test system for this study, AG129 mice infected with non-mouse adapted DEN-2 dengue virus strain, NGC, produced antigenemia and viremia as confirmed by the presence of NS1 and viral RNA in the plasma, respectively. The test item, freeze-dried CPLJ, mainly consists of flavonoid derivatives followed by hydroxycinnamic acids derivatives, alkaloid compounds, organic and phenolic acids. However, the oral administration of freeze-dried CPLJ (500 mg/kg/day and $1000 \mathrm{mg} / \mathrm{kg} /$ day) for 3 consecutive days did not affect the level of NS1 and viral RNA in the plasma of dengue virus-infected AG129 mice.

The development of NS1 antigenemia in infected AG129 mice showed the ability of non-mouse adapted NGC strain DEN-2 dengue virus to replicates in AG129 mice, which lack of interferon $\alpha / \beta$ and interferon $\gamma$ receptor genes. A similar kinetic pattern of NS1 has also been demonstrated in AG129 mice infected with other dengue virus strains, which peaked on day 3 to day 4 post infection and the concentration of NS1 in the plasma was positively dependent on the viral inoculation dose [50]. This study could not mimic the severe dengue condition because the clinical symptoms developed by AG129 mice infected with NGC strain DEN-2 dengue virus was limited to viremia and paralysis. The NGC 
Table 1 Compounds identification of freeze-dried C. papaya leaf juice by UPLC-HRAMS analysis

\begin{tabular}{|c|c|c|c|c|c|c|}
\hline No. & Compounds & Formula & Retention time (min) & $\begin{array}{l}\text { ESI Mode } \\
\text { (Negative/Positive) }\end{array}$ & $\begin{array}{l}\mathrm{MS}(\mathrm{m} / \mathrm{z}) / \mathrm{mass} \\
\text { error }(\mathrm{ppm})\end{array}$ & MS/MS fragments ions $(\mathrm{m} / \mathrm{z})$ \\
\hline 1 & ${ }^{*}$ Quinic acid & $\mathrm{C}_{7} \mathrm{H}_{12} \mathrm{O}_{6}$ & 0.46 & Negative & $91.05545 / 2.28$ & $102.94775,127.04004(100)$ \\
\hline 2 & *Malic Acid & $\mathrm{C}_{4} \mathrm{H}_{6} \mathrm{O}_{5}$ & 0.51 & Negative & 133.01434/1.19 & $\begin{array}{l}115.00343(100), 71.01169 \\
89.02279,75.00661\end{array}$ \\
\hline 3 & *Protocatechuic acid & $\mathrm{C}_{7} \mathrm{H}_{6} \mathrm{O}_{4}$ & 0.81 & Negative & $153.01880 / 3.69$ & $109.02846(100), 111.101892(10)$ \\
\hline 4 & ${ }^{*}$ Chlorogenic acid & $\mathrm{C}_{16} \mathrm{H}_{18} \mathrm{O}_{9}$ & 1.41 & Negative & $353.08746 / 2.13$ & 191.01953(100) \\
\hline 5 & ${ }^{*} p$-Coumaric acid & $\mathrm{C}_{9} \mathrm{H}_{8} \mathrm{O}_{3}$ & 2.63 & Positive & $165.05493 / 1.87$ & $\begin{array}{l}147.04439(100), 149.04929(30) \\
119.04953(20) 142.96738\end{array}$ \\
\hline 6 & ${ }^{*}$ Caffeic acid & $\mathrm{C}_{9} \mathrm{H}_{8} \mathrm{O}_{4}$ & 3.08 & Negative & $179.03476 / 2.26$ & $135.04527(100), 136.98357(10)$ \\
\hline 7 & ${ }^{* *}$ Manghaslin & $\mathrm{C}_{33} \mathrm{H}_{40} \mathrm{O}_{20}$ & 4.66 & Negative & $755.20654 / 4.79$ & $\begin{array}{l}300.02884(100), 301.03391(40), \\
271.02570,151.00323\end{array}$ \\
\hline 8 & ${ }^{* *}$ Clitorin & $\mathrm{C}_{33} \mathrm{H}_{40} \mathrm{O}_{19}$ & 4.74 & Negative & $739.20807 / 0.09$ & $\begin{array}{l}284.03326(100), 285.03860(50) \\
255.09275,151.00337\end{array}$ \\
\hline 9 & **Sinapic acid & $\mathrm{C}_{11} \mathrm{H}_{12} \mathrm{O}_{5}$ & 4.77 & Negative & $223.06154 / 1.44$ & $\begin{array}{l}164.04741(100), 149.02414(80), \\
208.03912(70), 170.07121(20)\end{array}$ \\
\hline 10 & ${ }^{* *}$ Isoquercetin & $\mathrm{C}_{21} \mathrm{H}_{20} \mathrm{O}_{12}$ & 4.83 & Negative & $463.09009 / 2.99$ & $\begin{array}{l}300.02841(100), 301.03516(60), \\
271.02573,402.06155\end{array}$ \\
\hline 11 & ${ }^{*}$ Ferulic Acid & $\mathrm{C}_{10} \mathrm{H}_{10} \mathrm{O}_{4}$ & 4.89 & Negative & 193.05016/3.24 & $\begin{array}{l}134.03703(100), 178.02638(30), \\
149.06056(10)\end{array}$ \\
\hline 12 & *Rutin & $\mathrm{C}_{27} \mathrm{H}_{30} \mathrm{O}_{16}$ & 4.94 & Negative & $609.14673 / 2.82$ & $\begin{array}{l}300.02887(100), 301.0583(80) \\
302.03983,151.00136\end{array}$ \\
\hline 13 & ${ }^{* *}$ Astragalin & $\mathrm{C}_{21} \mathrm{H}_{20} \mathrm{O}_{11}$ & 4.99 & Negative & $447.09494 / 2.75$ & $\begin{array}{l}284.03329(100), 285.03998(80), \\
255.03046(20), 327.05276\end{array}$ \\
\hline 14 & ${ }^{*}$ Nicotiflorin & $\mathrm{C}_{27} \mathrm{H}_{30} \mathrm{O}_{15}$ & 5.04 & Negative & $593.14807 / 2.65$ & 238.18059 (100), $256.191689(20), 137.09636$ \\
\hline 15 & ${ }^{* *}$ Dehydrocarpaine II & $\mathrm{C}_{28} \mathrm{H}_{48} \mathrm{~N}_{2} \mathrm{O}_{4}$ & 5.20 & Positive & $475.35425 / 2.34$ & $\begin{array}{l}284.03308(50), 285.03891(100) \\
273.11279,151.00275\end{array}$ \\
\hline 16 & ${ }^{* *}$ Dehydrocarpaine I & $\mathrm{C}_{28} \mathrm{H}_{48} \mathrm{~N}_{2} \mathrm{O}_{4}$ & 5.27 & Positive & $477.37003 / 2.82$ & 240.19635 (50), 220.16989, 256.19165 \\
\hline 17 & *Myricetin & $\mathrm{C}_{15} \mathrm{H}_{10} \mathrm{O}_{8}$ & 5.31 & Negative & $317.03104 / 4.82$ & $178.9979(80), 151.00313(60)$ \\
\hline 18 & ${ }^{* *}$ Carpaine & $\mathrm{C}_{28} \mathrm{H}_{50} \mathrm{~N}_{2} \mathrm{O}_{4}$ & 5.45 & Positive & $479.38556 / 2.56$ & $240.19623(100), 241,19969,222.18558$ \\
\hline 19 & *Fisetin & $\mathrm{C}_{15} \mathrm{H}_{10} \mathrm{O}_{6}$ & 5.78 & Negative & $285.0405 / 3.98$ & $163.00359(40), 135.00841$ (30) $121.0912(20)$ \\
\hline 20 & *Morin & $\mathrm{C}_{15} \mathrm{H}_{10} \mathrm{O}_{7}$ & 6.10 & Negative & $301.03564 / 4.52$ & 151.00308 (100), $229.05057(20)$ \\
\hline 21 & ${ }^{*}$ Quercetin & $\mathrm{C}_{15} \mathrm{H}_{10} \mathrm{O}_{7}$ & 6.94 & Negative & $301.03571 / 4.75$ & $\begin{array}{l}151.00320(100), 178.99736(50) \\
273.04007(20), 257.04529(20)\end{array}$ \\
\hline 22 & *Kaempferol & $\mathrm{C}_{15} \mathrm{H}_{10} \mathrm{O}_{6}$ & 7.47 & Negative & $285.04041 / 3.67$ & $151.00298(100), 229.9550$ \\
\hline 23 & * Citropten & $\mathrm{C}_{11} \mathrm{H}_{10} \mathrm{O}_{4}$ & 7.78 & Positive & $207.06567 / 2.34$ & $192.04166,163.07509(100)$ \\
\hline 24 & *Isorhamnetin & $\mathrm{C}_{16} \mathrm{H}_{12} \mathrm{O}_{7}$ & 7.84 & Negative & $315.0517 / 4.34$ & $300.02762(100), 151,00200(10)$ \\
\hline
\end{tabular}

${ }^{*}$ Compounds identified tentatively and confirmed with reference standards **Compounds identified tentatively

strain DEN-2 dengue virus was commonly use in viremia development or anti-viral studies [31, 51]. There were several non-mouse adapted dengue virus strains, which represent dengue hemorrhagic fever [36, 37, 52, 53]. For example, the D2Y98P strain DEN-2 dengue virus has been reported previously to be lethal and could cause plasma leakage in infected AG129 mice in less than 10 days post infection [37, 52]. As compared to this study, the infection with non-mouse adapted NGC strain DEN-2 dengue virus was lethal at later time point (day 11 post infection onwards). As the NGC strain DEN-2 dengue virus is neurovirulent, most of the infected AG129 mice were found paralyzed at later day of post infection, which could be due to the systemic infection in the brain [27]. However, not all dengue virus strains produced thrombocytopenia in AG129 mice. This includes the NGC strain DEN-2 dengue virus used in this study and D2Y98P strain DEN-2 dengue virus $[37,52]$. Thereby, this study was unable to observe any reduction of platelet level in the infected AG129 mice.

Out of 24 identified compounds, flavonoids derivatives followed by hydroxycinammic acids derivatives was majorly identified in the freeze-dried CPLJ. Similar findings were also reported by Anjum et al. [13] and Afzan et al. 


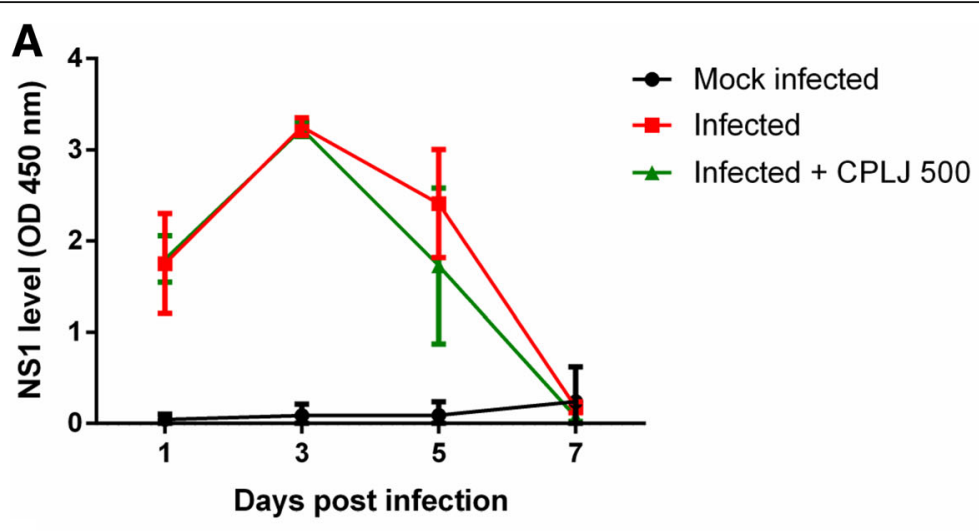

B

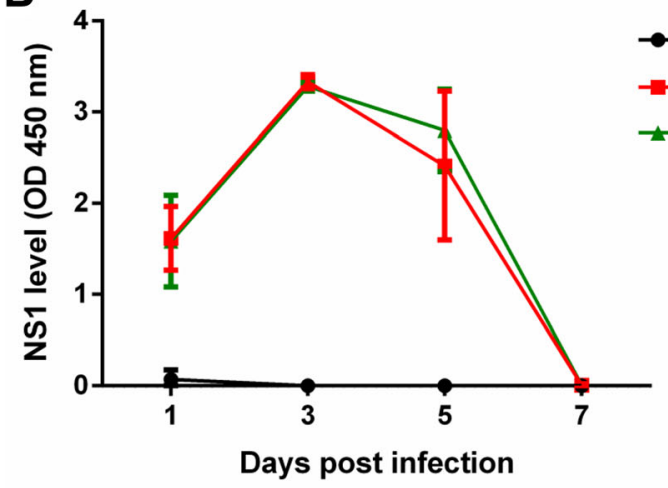

\section{Mock infected}

- Infected

$\star$ Infected + CPLJ 500

C

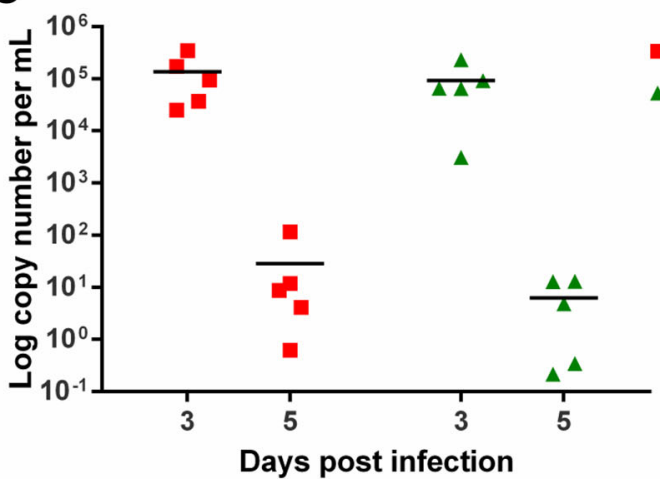

Fig. 3 The effect of freeze-dried CPL on the level of NS1 and viral RNA. AG129 mice inoculated with (a) $2 \times 10^{5}$ PFU and (b) $2 \times 10^{6}$ PFU dengue virus strain NGC were treated with $500 \mathrm{mg} / \mathrm{kg}$ BW of freeze-dried CPL once a day from day 1 to day 3 post infection. The NS1 levels in plasma of mock infected (black circles) ( $n=5)$, infected (red squares) ( $n=5)$ and infected+CPL 500 (green triangles) ( $n=5)$ AG129 mice groups were detected on day 1, 3 and 5 by NS1 antigen immunoassay. (c) The plasma viral RNA of infected (red squares) ( $n=5$ ) and infected+CPL 500 (green triangles) ( $n=5)$ AG129 mice groups ( $2 \times 10^{6}$ PFU) were detected by quantitative reverse transcription PCR on day 3 and day 5 post infections. Data represent mean values \pm standard deviations (SD)

[44] studies, which have highlighted the abundance of flavonoids and hydroxycinammic acids derivatives in the freeze-dried CPLJ. As based on the peak area, the dominant compounds were quinic acid, malic acid, manghaslin, clitorin, sinapsic acid, isoquercetin, ferulic acid, rutin, astragalin and nicotiflorin and carpaine. The clitorin, manghaslin and carpaine were also reported as dominant compounds in the freeze-dried CPLJ of 'Sekaki' cultivar by Afzan et al. [44].
The potential dengue anti-viral compounds such as quercetin and fisetin were among the identified compounds in the freeze-dried CPLJ. The dengue anti-viral activities of quercetin and fisetin were detected by in vitro studies with $50 \%$ inhibitory concentrations $\left(\mathrm{IC}_{50}\right)$ of $35.7 \mu \mathrm{g} / \mathrm{ml}$ and $55 \mu \mathrm{g} / \mathrm{ml}$, respectively [26, 54]. However, as the amount of quercetin and fisetin in the freeze-dried CPLJ could be low, the antiviral activities of these compounds may be hindered or not biologically 


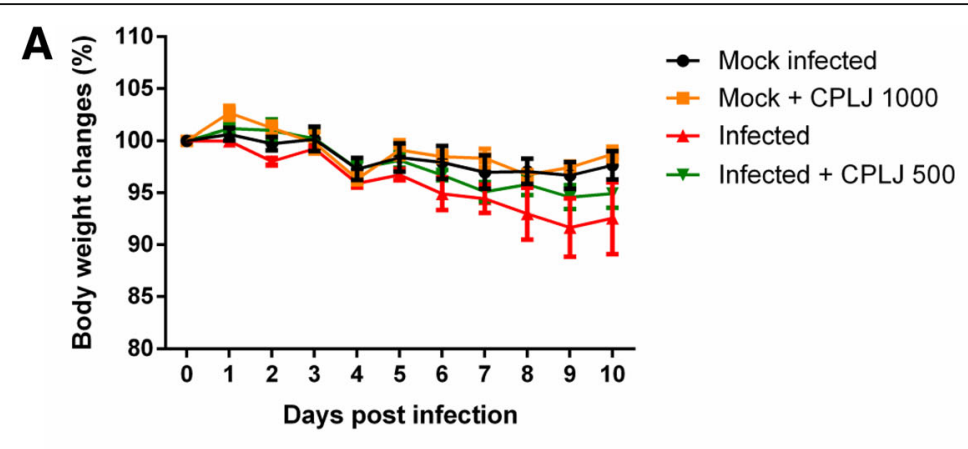

B

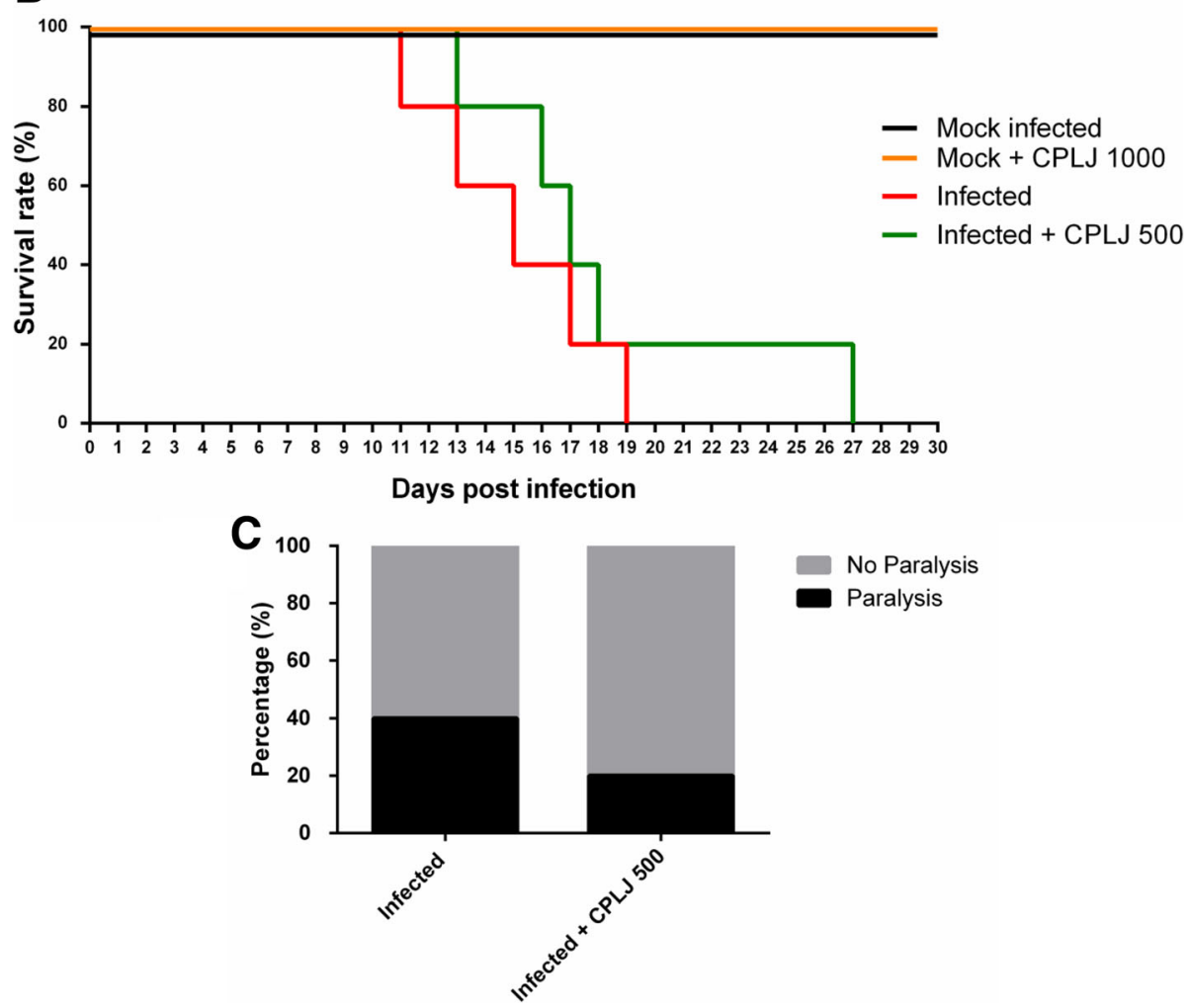

Fig. 4 The freeze-dried C. papaya leaves juice slightly affecting the morbidity development of AG129 mice infected with $2 \times 10^{6}$ PFU dengue virus. a Body weight changes of mock infected (black lines) ( $n=5)$, infected (red lines) ( $n=5$ ) and infected+CPLJ (green lines) ( $n=5)$ AG129 mice groups were monitored daily. Data represent mean values \pm standard error of the mean (SEM). $\mathbf{b}$ Number of moribund AG129 mice in mock infected (black lines) $(n=5)$, mock+CPL 1000 (orange line) ( $n=5)$, infected (red lines) $(n=5)$ and infected+CPL 500 (green lines) ( $n=5)$ groups were recorded daily for 30 days post infection. Kaplan-Meier curves illustrated the susceptibility of AG129 mice to dengue virus. Percentage of survival between experimental groups were compared using Log-rank (Mantel-Cox) test. However, the survival differences were not statistically significant between infected and infected+CPL 500 groups. c The number of mice developing paralysis (complete paralysis of one or both hindlimbs) were recorded for 30 days post infection. Data represent percentages of total moribund AG129 mice with and without sign of paralysis

effective in vivo. In addition, the doses and treatment duration used in this study might not be sufficient to inhibit dengue virus replication in vivo. This is because the doses and treatment duration as implemented in this study (therapeutic dose: $500 \mathrm{mg} / \mathrm{kg} /$ day and high dose: $1000 \mathrm{mg} / \mathrm{kg} /$ day; 3 consecutive days) were based on the clinical trial conducted for the assessment of thrombocytosis activity [12] but not for its antiviral activity. Therefore, in order to better understand the effective anti-viral doses and treatment duration of freeze-dried CPLJ, a pharmacokinetic study for at least 3 different doses (low, medium and high doses) need to be conducted in the future.

Although freeze-dried CPLJ treatment was not affecting the plasma viral RNA level, the potential effect of freeze-dried CPLJ on the organ's viremia could not be excluded. However, due to the nature of this study (observational study), the possible effect of 


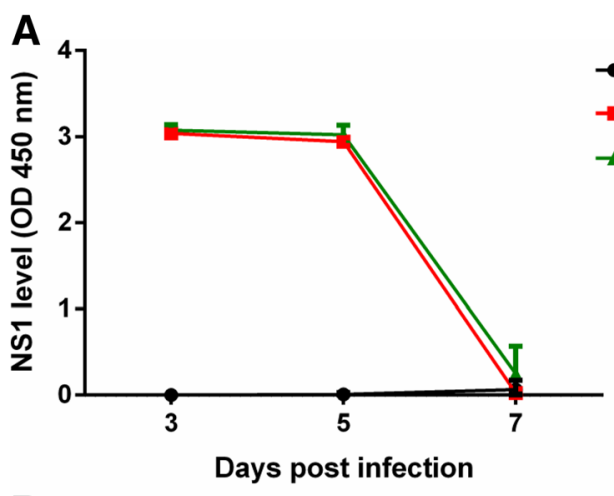

B

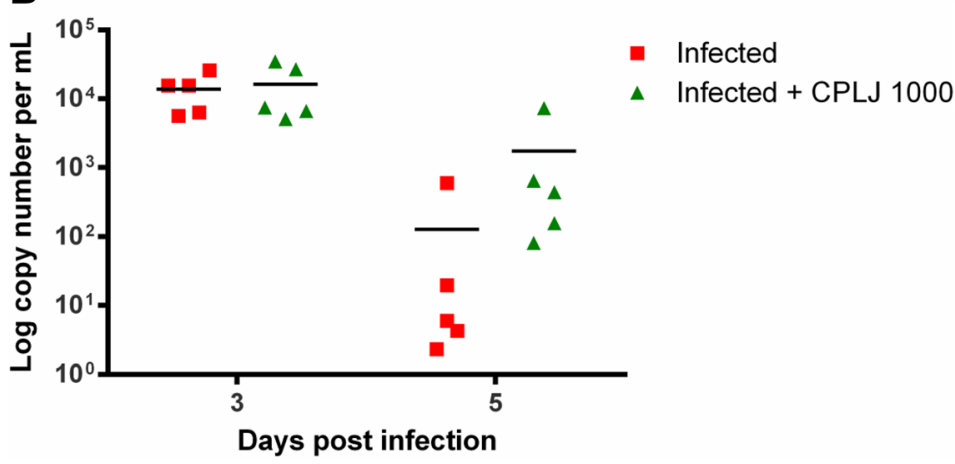

Fig. 5 An independent experiment showing that $1000 \mathrm{mg} / \mathrm{kg}$ BW freeze-dried C. papaya leaf juice was not affecting plasma NS1 and viral RNA levels in AG129 mice during dengue infection. (a) AG129 mice infected with dengue virus strain NGC ( 2 X 10 PFU) were treated with 1000 mg/ $\mathrm{kg}$ BW of freeze-dried CPLJ daily from day 1 to day 3 post infection. The plasma NS1 level of mock infected (black circles) ( $n=5)$, infected (red squares) ( $n=5)$ and infected+CPLJ 1000 (green triangles) ( $n=5)$ AG129 mice groups were detected on day 3,5 and 7 by NS1 antigen immunoassay. (b) The plasma viral RNA of infected (red squares) ( $n=5)$ and infected+CPLJ 1000 (green triangles) ( $n=5$ ) AG129 mice groups were detected by quantitative reverse transcription PCR on day 3 and day 5 post infections. Data represent mean values \pm SD

freeze-dried CPLJ treatment on dengue virus viability in the organs such as liver, spleen, kidney and brain could not be highlighted. While dengue patients are commonly viremic at the time of treatment, studying the effect of $C$. papaya juice at different phases of dengue clinical development, febrile phase (early infection, peak viremia) and critical phase is important to discover the optimal administration of the juice in clinical settings.

The dengue fever mouse model in this study was not exactly representing the patient's condition in the clinical setting as reported in previous studies [10-12]. Other than the viremic condition of dengue patients, the enrolled dengue patients in $C$. papaya juice clinical trial were treated with $C$. papaya leaf juice together with the implementation of standard dengue management such as hydration and paracetamol treatments. Hence, whether or not, the $C$. papaya leaf juice exhibit synergistic effect when used in combination with the standard dengue management (at least with paracetamol combination) in dengue mouse model and how this combination therapy affects the dengue virus development remains to be elucidated.

\section{Conclusion}

The findings indicated that 3 days treatment of $500 \mathrm{mg} /$ $\mathrm{kg} /$ day and $1000 \mathrm{mg} / \mathrm{kg} /$ day of freeze-dried CPLJ at early point of infection or at the onset of viremia (Day 1 to Day 3 post infection) did not affect the plasma NS1 and viral RNA levels in dengue fever AG129 mice model. More studies need to be conducted in order to validate the findings, with special attention to the dose, the duration of treatment, and potential use of CPLJ in adjunctive therapy.

\section{Additional file}

Additional file 1: The survival rate of AG129 mice infected with $2 \times 10^{5}$ PFU and $2 \times 10^{6}$ PFU NGC strain dengue virus. (PDF $29 \mathrm{~kb}$ )

\section{Acknowledgements}

We would like to thank the Director General of Health Malaysia for his permission to publish this article. We wish to thank Ms. Adlin Afzan, Phytochemistry Unit, Herbal Medicine Research Center, Institute for Medical Research, Kuala Lumpur, Malaysia for her consultation on the mass spectrometry analysis of freeze-dried CPLJ. We also would like to thank the staff of Bioassay, Phytochemistry and Toxicology and Pharmacology Units, Herbal Medicine Research Centre, Institute for Medical Research, Kuala Lumpur, Malaysia who has contributed in this study. 


\section{Funding}

This study was funded by Ministry of Health Malaysia. The funding body has no role in the design of the study and collection, analysis, and interpretation of data and in writing the manuscript.

\section{Availability of data and materials}

The datasets used and/or analysed during the current study are available from the corresponding author on reasonable request.

\section{Authors' contributions}

MRMAR participated in the design of the study, data analysis and drafted the manuscript. MZ, HM and AFSM participated in the design of the animal study, NHMJ and RT carried out the dengue virus propagation and titer quantitation, AM and URS carried out the bleeding, necropsy and sample processing of the study animals, THCD carried out the morbidity and mortality monitoring and analysis, BJ carried out the dengue viral RNA quantitation, NAN performed the NS1 assay, NMM and MIW prepared and analyzed the freeze-dried C. papaya leaf juice fingerprinting. All authors read and approved the final manuscript.

\section{Ethics approval and consent to participate}

All animal experiment procedures were carried out under the guidelines and upon approval of the Animal Care and Use Committee, Ministry of Health Malaysia (ACUC-MOH), (ACUC/KKM/02(9/2016).

\section{Consent for publication}

Not applicable.

\section{Competing interests}

The authors declare that they have no competing interests.

\section{Publisher's Note}

Springer Nature remains neutral with regard to jurisdictional claims in published maps and institutional affiliations.

\section{Author details}

${ }^{1}$ Herbal Medicine Research Center, Institute for Medical Research, Kuala Lumpur, Malaysia. ${ }^{2}$ Infectious Disease Research Center, Institute for Medical Research, Kuala Lumpur, Malaysia.

Received: 4 June 2018 Accepted: 27 November 2018 Published online: 05 December 2018

\section{References}

1. Fact sheets: Dengue and severe dengue. http://www.who.int/news-room/ fact-sheets/detail/dengue-and-severe-dengue. Accessed 9 Aug 2018.

2. Low JG, Ooi EE, Vasudevan SG. Current Status of Dengue Therapeutics Research and Development. J Infect Dis. 2017;215(suppl_2):S96-S102.

3. WHO advises Dengvaxia be used only in people previously infected with dengue. http://www.who.int/medicines/news/2017/WHO-advises-dengvaxiaused-only-in-people-previously-infected/en/. Accessed 21 Sept 2018.

4. Ching S, Ramachandran V, Gew LT, Lim SM, Sulaiman WA, Foo YL, Zakaria ZA, Samsudin NH, Lau PC, Veettil SK, et al. Complementary alternative medicine use among patients with dengue fever in the hospital setting: a cross-sectional study in Malaysia. BMC Complement Altern Med. 2016;16:37.

5. Charan J, Saxena D, Goyal JP, Yasobant S. Efficacy and safety of Carica papaya leaf extract in the dengue: A systematic review and meta-analysis. Int J Appl Basic Med Res. 2016;6(4):249-54

6. Kala CP. Leaf juice of Carica papaya L.: A remedy of dengue fever. Med Aromatic Plants. 2012;1(6):1000109.

7. Hettige S. Salutary effects of Carica papaya leaf extract in dengue fever patients-a pilot study. Sri Lankan Family Physician. 2008;29:17-9.

8. Siddique O, Sundus A, Ibrahim MF. Effects of papaya leaves on thrombocyte counts in dengue-case report. J Pak Med Assoc. 2014;64(3):364-6.

9. Ahmad N, Fazal H, Ayaz M, Abbasi BH, Mohammad I, Fazal L. Dengue feve treatment with Carica papaya leaves extracts. Asian Pacific J Trop Biomed. 2011;1(4):330-3.

10. Gadhwal AK, Ankit BS, Chahar C, Tantia P, Sirohi P, Agrawal RP. Effect of Carica papaya Leaf Extract Capsule on Platelet Count in Patients of Dengue Fever with Thrombocytopenia. J Assoc Physicians India. 2016;64(6):22-6.
11. Gowda AC, Kumar NV, Kasture PN, Nagabhushan KH. A pilot study to evaluate the effectiveness of Carica papaya leaf extract in increasing the platelet count in cases of dengue with thrombocytopenia. Indian Medica Gazette. 2015:109-16.

12. Subenthiran S, Choon TC, Cheong KC, Thayan R, Teck MB, Muniandy PK, Afzan A, Abdullah NR, Ismail Z. Carica papaya Leaves Juice Significantly Accelerates the Rate of Increase in Platelet Count among Patients with Dengue Fever and Dengue Haemorrhagic Fever. Evidence-based Complement Altern Med : eCAM. 2013;2013:616737.

13. Anjum V, Arora P, Ansari SH, Najmi AK, Ahmad S. Antithrombocytopenic and immunomodulatory potential of metabolically characterized aqueous extract of Carica papaya leaves. Pharm Biol. 2017;55(1):2043-56.

14. Dharmarathna SL, Wickramasinghe S, Waduge RN, Rajapakse RP, Kularatne SA. Does Carica papaya leaf-extract increase the platelet count? An experimental study in a murine model. Asian Pacific J Trop Biomed. 2013;3(9):720-4

15. Gammulle A, Ratnasooriya WD, Jayakody JRAC, Fernando C, Kanatiwela C, Udagama PV. Thrombocytosis and anti-inflammatory properties, and toxicological evaluation of Carica papaya mature leaf concentrate in a murine model. Online Int J Med Plants Res. 2012;1(2):21-30.

16. Jayasinghe CD, Gunasekera DS, De Silva N, KKM J, Udagama PV. Mature leaf concentrate of Sri Lankan wild type Carica papaya Linn. modulates nonfunctional and functional immune responses of rats. BMC Complement Altern Med. 2017;17(1):230.

17. Sathasivam K, Ramanathan S, Mansor SM, Haris MR, Wernsdorfer WH, Thrombocyte counts in mice after the administration of papaya leaf suspension. Wiener klinische Wochenschrift. 2009;121(Suppl 3):19-22.

18. Tahir N, Zaheer Z, Kausar S, Chiragh S. Prevention of fall in platelet count by Carica papaya leaf juice in carboplatin induced thrombocytopaenia in mice. Biomedica. 2014;30(1):21-5.

19. Zunjar V, Dash RP, Jivrajani M, Trivedi B, Nivsarkar M. Antithrombocytopenic activity of carpaine and alkaloidal extract of Carica papaya Linn. leaves in busulfan induced thrombocytopenic Wistar rats. Journal Ethnopharmacol. 2016;181:20-5.

20. Beatty PR, Puerta-Guardo H, Killingbeck SS, Glasner DR, Hopkins K, Harris E. Dengue virus NS1 triggers endothelial permeability and vascular leak that is prevented by NS1 vaccination. Sci Transl Med. 2015;7(304):304ra141.

21. Lin CF, Lei HY, Shiau AL, Liu HS, Yeh TM, Chen SH, Liu CC, Chiu SC, Lin YS. Endothelial cell apoptosis induced by antibodies against dengue virus nonstructural protein 1 via production of nitric oxide. J Immunol. 2002;169(2):657-64.

22. Modhiran N, Watterson D, Muller DA, Panetta AK, Sester DP, Liu L, Hume DA, Stacey KJ, Young PR. Dengue virus NS1 protein activates cells via Tolllike receptor 4 and disrupts endothelial cell monolayer integrity. Sci Transl Med. 2015;7(304):304ra142.

23. Puerta-Guardo H, Glasner DR, Harris E. Dengue Virus NS1 Disrupts the Endothelial Glycocalyx, Leading to Hyperpermeability. PLoS Pathog. 2016;12(7):e1005738

24. Wan SW, Yang YW, Chu YT, Lin CF, Chang CP, Yeh TM, Anderson R, Lin YS Anti-dengue virus nonstructural protein 1 antibodies contribute to platelet phagocytosis by macrophages. Thromb Haemost. 2016;115(3):646-56.

25. Senthilvel P, Lavanya P, Kumar KM, Swetha R, Anitha P, Bag S, Sarveswari S, Vijayakumar V, Ramaiah S, Anbarasu A. Flavonoid from Carica papaya inhibits NS2B-NS3 protease and prevents Dengue 2 viral assembly. Bioinformation. 2013;9(18):889-95.

26. Zandi K, Teoh BT, Sam SS, Wong PF, Mustafa MR, Abubakar S. Antiviral activity of four types of bioflavonoid against dengue virus type-2. J Virol. 2011;8:560.

27. Johnson AJ, Roehrig JT. New mouse model for dengue virus vaccine testing. J Virol. 1999;73(1):783-6.

28. Zellweger RM, Shresta S. Mouse models to study dengue virus immunology and pathogenesis. Front Immunol. 2014;5:151.

29. van den Broek MF, Muller U, Huang S, Aguet M, Zinkernagel RM. Antiviral defense in mice lacking both alpha/beta and gamma interferon receptors. J Virol. 1995;69(8):4792-6.

30. Aliota MT, Caine EA, Walker EC, Larkin KE, Camacho E, Osorio JE. Characterization of Lethal Zika Virus Infection in AG129 Mice. PLoS Negl Trop Dis. 2016;10(4):e0004682.

31. Martinez-Gutierrez M, Correa-Londono LA, Castellanos JE, Gallego-Gomez JC, Osorio JE. Lovastatin delays infection and increases survival rates in AG129 mice infected with dengue virus serotype 2. PLoS One. 2014;9(2):e87412. 
32. Sood R, Raut R, Tyagi P, Pareek PK, Barman TK, Singhal S, Shirumalla RK, Kanoje V, Subbarayan R, Rajerethinam R, et al. Cissampelos pareira Linn: Natural Source of Potent Antiviral Activity against All Four Dengue Virus Serotypes. PLoS Negl Trop Dis. 2015;9(12):e0004255.

33. Warfield KL, Plummer EM, Sayce AC, Alonzi DS, Tang W, Tyrrell BE, Hill ML, Caputo AT, Killingbeck SS, Beatty PR, et al. Inhibition of endoplasmic reticulum glucosidases is required for in vitro and in vivo dengue antiviral activity by the iminosugar UV-4. Antiviral Res. 2016;129:93-8.

34. Watanabe S, Chan KW, Dow G, Ooi EE, Low JG, Vasudevan SG. Optimizing celgosivir therapy in mouse models of dengue virus infection of serotypes 1 and 2: The search for a window for potential therapeutic efficacy. Antiviral Res. 2016;127:10-9.

35. Milligan GN, Sarathy W, Infante E, Li L, Campbell GA, Beatty PR, Harris E, Barrett AD, Bourne N. A Dengue Virus Type 4 Model of Disseminated Lethal Infection in AG129 Mice. PLoS One. 2015;10(5):e0125476.

36. Sarathy W, White M, Li L, Gorder SR, Pyles RB, Campbell GA, Milligan GN, Bourne N, Barrett AD. A lethal murine infection model for dengue virus 3 in AG129 mice deficient in type I and II interferon receptors leads to systemic disease. J Virol. 2015;89(2):1254-66.

37. Tan GK, Ng JK, Trasti SL, Schul W, Yip G, Alonso S. A non mouse-adapted dengue virus strain as a new model of severe dengue infection in AG129 mice. PLoS Negl Trop Dis. 2010;4(4):e672.

38. Sarathy W, White M, Li L, Kaiser JA, Campbell GA, Milligan GN, Bourne N, Barrett ADT. Characterization of a murine model of non-lethal, symptomatic dengue virus infection. Sci Rep. 2018;8(1):4900.

39. Diamond MS, Edgil D, Roberts TG, Lu B, Harris E. Infection of human cells by dengue virus is modulated by different cell types and viral strains. J Virol. 2000;74(17):7814-23.

40. Phanthanawiboon SA, A-nuegoonpipat A, Panngarm N, Limkittikul K, Ikuta K, Anantapreecha S, Kurosu T. Isolation and propagation of Dengue virus in Vero and BHK-21 cells expressing human DC-SIGN stably. J Virol Methods. 2014;209:55-61.

41. Manning JS, Collins JK. Effects of cell culture and laboratory conditions on type 2 dengue virus infectivity. J Clin Microbiol. 1979;10(2):235-9.

42. Orozco S, Schmid MA, Parameswaran P, Lachica R, Henn MR, Beatty R, Harris E. Characterization of a model of lethal dengue virus 2 infection in C57BL/6 mice deficient in the alpha/beta interferon receptor. J Gen Virol. 2012:93(Pt 10):2152-7.

43. Ismail Z, Halim SZ, Abdullah NR, Afzan A, Abdul Rashid BA, Jantan I. Safety Evaluation of Oral Toxicity of Carica papaya Linn. Leaves: A Subchronic Toxicity Study in Sprague Dawley Rats. Evidence-based Complement Altern Med : eCAM. 2014;2014:741470

44. Afzan A, Abdullah NR, Halim SZ, Rashid BA, Semail RH, Abdullah N, Jantan I, Muhammad H, Ismail Z. Repeated dose 28-days oral toxicity study of Carica papaya L. leaf extract in Sprague Dawley rats. Molecules. 2012;17(4):4326-42.

45. Halim SZ, Abdullah NR, Afzan A, Abdul Rashid BA, Jantan I, Ismail Z. Acute toxicity study of Carica papaya leaf extract in Sprague Dawley rats. J Med Plant Res. 2011:5(10):1867-72.

46. Reagan-Shaw S, Nihal M, Ahmad N. Dose translation from animal to human studies revisited. Faseb J. 2008;22(3):659-61.

47. Francisco CC, Howarth GS, Whittaker AL. Effects on animal wellbeing and sample quality of 2 techniques for collecting blood from the facial vein of mice. J Am Assoc Lab Anim Sci. 2015;54(1):76-80.

48. Wang WK, Sung TL, Tsai YC, Kao CL, Chang SM, King CC. Detection of dengue virus replication in peripheral blood mononuclear cells from dengue virus type 2 -infected patients by a reverse transcription-real-time PCR assay. J Clin Microbiol. 2002;40(12):4472-8.

49. Chutinimitkul S, Payungporn S, Theamboonlers A, Poovorawan Y. Dengue typing assay based on real-time PCR using SYBR Green I. J Virol Methods. 2005;129(1):8-15.

50. Watanabe S, Tan KH, Rathore AP, Rozen-Gagnon K, Shuai W, Ruedl C, Vasudevan SG. The magnitude of dengue virus NS1 protein secretion is strain dependent and does not correlate with severe pathologies in the mouse infection model. J Virol. 2012;86(10):5508-14.

51. Stein DA, Huang CY, Silengo S, Amantana A, Crumley S, Blouch RE, Iversen PL, Kinney RM. Treatment of AG129 mice with antisense morpholino oligomers increases survival time following challenge with dengue 2 virus. J Antimicrob Chemother. 2008;62(3):555-65.
52. Tan GK, Ng JK, Lim AH, Yeo KP, Angeli V, Alonso S. Subcutaneous infection with non-mouse adapted Denque virus D2Y98P strain induces systemic vascular leakage in AG129 mice. Ann Acad Med Singapore. 2011;40(12):523-32.

53. Sarathy W, Infante E, Li L, Campbell GA, Wang T, Paessler S, Robert Beatty P, Harris E, Milligan GN, Bourne N, et al. Characterization of lethal dengue virus type 4 (DENV-4) TVP-376 infection in mice lacking both IFN-alpha/beta and IFN-gamma receptors (AG129) and comparison with the DENV-2 AG129 mouse model. J Gen Virol. 2015;96(10):3035-48.

54. Zandi K, Teoh BT, Sam SS, Wong PF, Mustafa MR, AbuBakar S. In vitro antiviral activity of fisetin, rutin, and naringenin against dengue virus type- 2 . Jed Plants Res. 2011;5(23):5534-9.

\section{Ready to submit your research? Choose BMC and benefit from:}

- fast, convenient online submission

- thorough peer review by experienced researchers in your field

- rapid publication on acceptance

- support for research data, including large and complex data types

- gold Open Access which fosters wider collaboration and increased citations

- maximum visibility for your research: over $100 \mathrm{M}$ website views per year

At BMC, research is always in progress.

Learn more biomedcentral.com/submissions 